NBER WORKING PAPER SERIES

\title{
THE IMPACT OF WELFARE BENEFITS ON SINGLE MOTHERHOOD AND HEADSHIP OF YOUNG WOMEN: EVIDENCE FROM THE CENSUS
}

\author{
Francine D. Blau \\ Lawrence M. Kahn \\ Jane Waldfogel \\ Working Paper 9338 \\ http://www.nber.org/papers/w9338
}

\author{
NATIONAL BUREAU OF ECONOMIC RESEARCH \\ 1050 Massachusetts Avenue \\ Cambridge, MA 02138
}

November 2002

This research was supported by a grant from the Russell Sage Foundation. Deborah Anderson, John Cheslock, Wen-Jui Han, Elizabeth Inez Johnson, Brian Levine, Joan Moriarty, and Andre Souza provided excellent research assistance. We are also grateful to Al Anderson for help with the Census extracts, and to Robert Moffitt and Hilary Hoynes for providing us with data on welfare benefits. Special thanks are due to John Bound and Harry Holzer for their considerable help in making some key data on matching Metropolitan Statistical Areas (MSAs) across Censuses available to us. The views expressed herein are those of the authors and not necessarily those of the National Bureau of Economic Research.

(C) 2002 by Francine D. Blau, Lawrence M. Kahn, and Jane Waldfogel. All rights reserved. Short sections of text, not to exceed two paragraphs, may be quoted without explicit permission provided that full credit, including (C) notice, is given to the source. 
The Impact of Welfare Benefeits on Single Motherhood and Headship of Young Women: Evidence from the Census Francine D. Blau, Lawrence M. Kahn, and Jane Waldfogel NBER Working Paper No. 9338

November 2002

JEL No. I3, J1

\section{$\underline{\text { ABSTRACT }}$}

This paper uses data from the 1970, 1980 and 1990 Censuses to investigate the impact of welfare benefits across Metropolitan Statistical Areas (MSAs) on the incidence of single motherhood and headship for young women. A contribution of the paper is the inclusion of both MSA fixed effects and MSA-specific time trends to account for fixed and trending unmeasured factors that could influence both welfare benefit levels and family formation. In such a model, we find no effect of welfare benefits on single motherhood for whites or blacks, and a positive effect of welfare benefits on single headship only for blacks.

Francine D. Blau

School of Industrial and Labor Relations Cornell University

265 Ives Hall

Ithaca, NY 14853

NBER and CESifo

fdb4@cornell.edu
Lawrence M. Kahn

School of Industrial and Labor Relations Cornell University

264 Ives Hall

Ithaca, NY 14853

and CESifo

lmk12@cornell.edu

Jane Waldfogel

Columbia University School of Social Work

622 W. 113th Street

New York, NY 10025

jw205@columbia.edu 


\section{Introduction}

In 1996, Congress enacted legislation designed to radically overhaul the welfare system in the United States. The Personal Responsibility and Work Opportunity Reconciliation Act of 1996 increases work requirements for welfare recipients, takes away their unconditional entitlement to benefits, and limits total benefit receipt to five years (Blank 1997). Part of the rationale for this legislation was a belief that Aid to Families with Dependent Children (AFDC), which up to 1996 was the major welfare program in the US, contributed to the incidence of single parent families. The share of children who will spend at least some portion of their childhood with a single parent now surpasses the fifty percent mark (McLanahan and Sandefur 1994). Growing up without a father present, the most common outcome in a single parent family, is blamed for a variety of social problems, including the transmission of poverty and its consequences across generations. There is particular concern when the mother is herself very young. Although reducing single household headship (as opposed to single parenthood) was not the primary goal of the recent welfare reforms, it is also thought by some that outcomes for children are worse when single parents form their own households, rather than live with their own parents or other relatives. Again, there is particular concern when the single parent is herself very young.

An extensive literature has attempted to assess the impact of welfare on the incidence of single motherhood. The wide variation in benefit levels across states has provided researchers with the opportunity to estimate the impact of differences in these benefits on family formation outcomes. ${ }^{1}$ Of course, as has been noted by many, welfare benefits have been falling in real terms since the 1970s, implying that the increase in single parenthood cannot be attributed to rising welfare benefits (Moffitt 1998; Hoynes 1997). Nonetheless, it is still possible for

\footnotetext{
1 For surveys, see Moffitt (1992 and 1998).
} 
decreased benefit levels to lower the incidence of single motherhood, so the issue of the effect of welfare on single motherhood remains of considerable interest.

Early work on this question was based on cross-sectional analyses relating welfare benefit levels in a state to the family formation decisions of women in that state (Danziger et al. 1982; Ellwood and Bane 1985; Moffitt 1990). Yet, as pointed out by Ellwood and Bane (1985), Moffitt (1994) and Hoynes (1997), such analyses may yield biased estimates if unmeasured factors such as state-specific norms affect both the level of welfare benefits and single parenthood. For example, states where people frown upon a single parent lifestyle may well enact low levels of welfare benefits, reflecting these beliefs, which may ultimately stem from religious or historical sources (for example, the culture of originally immigrating populations in a state). Or, as another example, there may be economic factors, such as labor market conditions, that vary systematically across states and that are not completely captured by included control variables. In both these cases, cross-sectional analyses may produce a spurious correlation between welfare benefit levels and the incidence of single parenthood. This possibility has led researchers such as Moffitt (1994) and Hoynes (1997) to estimate fixed effects models that in principle control for the impact of these unmeasured factors.

Yet even fixed effects methods may yield biased estimates if there are unmeasured changes in norms or other factors that are correlated with changes in welfare benefits. For example, states where the stigma placed on single parents is eroding faster may enact larger increases in welfare benefit levels and experience larger increases in single parenthood, or more rapidly deteriorating economic conditions in a state may result in larger increases in both welfare benefits and single parenthood. Further examples are provided by the "tax revolt" in California in 1978 and the fiscal crisis in New York in 1975, which produced changes in the climate for 
welfare support and possibly the social acceptance of single parenthood. Merely characterizing these two states as permanently liberal (as a state fixed effect model implicitly does) misses these important changes in the fiscal and social climate. ${ }^{2}$

A major contribution of this paper is to address this problem by using three waves of the Census of Population (1970, 1980 and 1990) to take account not only of Metropolitan Statistical Area (MSA) fixed effects, but also of changing norms and other unmeasured trending factors at the metropolitan area level, through the inclusion of MSA-specific time trends. An additional contribution of our paper is that the large sample sizes in the Census permit us to include more detailed measures of MSA labor and marriage market conditions than earlier research does. Our focus on MSAs is guided by the view that MSAs more closely approximate labor markets than the state-level data used in much previous work. The large sample sizes in the Census also allow us to conduct a separate analysis of less educated women. We are thus able to compare welfare effects for the less educated with average overall welfare effects, providing a sharper test of the impact of welfare than simply estimating one overall welfare coefficient.

Consistent with earlier research on the impact of welfare, we find positive cross-sectional associations between welfare benefits and single motherhood and single headship. Similar to results obtained by Moffitt (1994) and Hoynes (1997) who use data other than the Census, we find that when we add MSA fixed effects, some evidence of positive impacts on single headship remains for black women overall and for less educated black women, but there is no evidence of positive welfare effects for whites. ${ }^{3}$ Further, adding MSA fixed effects eliminates any positive welfare effect on

\footnotetext{
2 To some degree, changes such as those described for California and New York can be proxied by political measures such as Democratic Party representation at the state level, and in some of our analyses, we use such measures. However, changing norms and values probably influence the behavior of Democrats (and Republicans), and such changes will not be captured by the standard political variables.

${ }^{3}$ Note that Moffitt's findings for blacks became insignificant under some state fixed effects specifications, and as discussed below, Hoynes' findings for blacks became insignificant when individual fixed effects were added to the
} 
single motherhood for all groups. Finally, when we include MSA-specific time trends, a positive effect of welfare benefits on single headship for young black women overall and for young less educated black women remains, with some evidence of a larger effect for the less educated. We continue to find no evidence of positive welfare effects for whites (for either single motherhood or headship) or for single motherhood for blacks. We conclude that for black women, particularly the less educated, limiting welfare benefits may well raise the incidence of extended family living arrangements but without affecting single parenthood. This lends support to one of the most robust results obtained in this literature, initially reported by Ellwood and Bane (1985) and Danziger et al. (1982), that welfare changes primarily affect the living arrangements of single mothers rather than single motherhood per se.

\section{Prior Research on the Effect of Welfare on Family Formation Outcomes and Contribution of This Study}

We are concerned with two outcomes for women: single motherhood and single mother household headship (which we call "single headship"). Each of these outcomes is joint in the sense that in order, for example, to be a single mother, one must be single and a mother. Theories designed to explain this joint outcome must speak to both components, and in the case of single headship, the third component of heading one's own household. Becker's (1981) theory of marriage has provided the theoretical basis for much of the empirical work on this issue. His framework depicts women as choosing their marriage, fertility and household headship status to maximize their utility. Central to Becker's (1981) theory are the opportunity cost of women's time and the gains to specialization in marriage. 
Under AFDC, welfare benefits were not available to women without children (although programs such as disability benefits or state-funded general assistance benefits might have been in some cases) and were unavailable or much more difficult to obtain if one was married. ${ }^{4}$ Thus, the welfare system in effect subsidized single parenthood. Further, welfare benefits were more difficult to qualify for if a single parent was living with other relatives such as parents, aunts or uncles (Ellwood and Bane 1985; Hutchens, Jakubson, and Schwartz 1989). This meant that welfare provided an especially large subsidy for single parents who headed their own households. Thus, theory unambiguously predicts a positive effect of AFDC benefits on single motherhood and single headship.

In addition to welfare policy, Becker's (1981) framework predicts important roles for male and female labor market conditions in influencing women's choices about family formation and living arrangements. The larger the opportunity cost of a woman's time (typically measured as better labor market opportunities), the less likely she is to choose to bear children. And the larger the gains to marriage, the more likely she is to be married. A major factor influencing the gains to marriage is the availability of suitable partners (see, for example, Becker 1981; Wilson 1987; Ellwood and Crane 1990; Darity, Myers, and Bowman 1995). All else equal, the larger the supply of marriageable men and the better their labor market prospects, the greater women's likelihood of being married. Moreover, the better a woman's own labor market opportunities, the less she will gain from marriage, ceteris paribus.

While better female labor markets are predicted to lower the incidence of marriage and children, their effects on the incidence of single motherhood are theoretically ambiguous. On the one hand, a better female labor market lowers the gain to marriage and thus raises the size of the

\footnotetext{
${ }^{4}$ Benefits available to married couples in some cases through the AFDC-Unemployed Parent (AFDC-UP) program
} 
group of women at risk of becoming single mothers; on the other hand, better female job prospects lower the incidence of children, reducing the size of this "at risk" group. Improvements in male labor markets and greater availability of marriageable men have similarly ambiguous theoretical effects on single motherhood. This is the case because, while they raise the likelihood that women will marry, the resulting increase in marriage (and possibly cohabitation as well) also increases the incidence of children. The higher incidence of children raises the size of the group that is at risk of eventually becoming single parents through separation, divorce or death of a spouse. Finally, the lower the cost relative to the benefits of forming one's own household, the more likely one is to be a household head. Welfare is the primary factor considered here, although other factors such as housing costs could also play a role (Winkler 1992). ${ }^{5}$

There has been a good deal of prior empirical research on the impact of welfare on women's family formation and fertility. In a review of this literature, Moffitt (1998) reaches the following conclusions. First, studies more often than not have found that welfare benefits have a negative effect on marriage and a positive effect on fertility, although often these effects are small, many studies find no significant effects at all, and others provide mixed results. One area in which the many studies of the impact of welfare on demographic outcomes have provided fairly consistent results is in the impact of welfare on single headship: studies have usually found that higher welfare benefits encourage single mothers to form their own households rather than to stay within households with other adult relatives (see, for example, Danziger et al. 1982; Ellwood and Bane 1985; Hutchens, Jakubson, and Schwartz 1989; Moffitt 1994). ${ }^{6}$ However,

were considerably more difficult to obtain than the traditional AFDC benefits available to single parents.

5 Unfortunately, the US Department of Housing and Urban Development (HUD) has "fair-market" rent data available by MSA only since 1983. Thus, we lack the necessary information to include data on rents in our full set of analyses.

6 A recent paper by $\mathrm{Hu}$ (2001) points out a countervailing effect working to increase incentives for respondents under 18 to remain in their parent's household when their parent is eligible for welfare: since welfare benefits 
even here, some negative effects have also been obtained (Moffitt 1990). A second conclusion that emerges from Moffitt's (1998) review is that, when analyses are disaggregated by race, positive welfare effects tend to be larger, and are found more often for whites than for blacks, although here again there is no consistent pattern of results across the many studies that have been conducted. As we will see below, conclusions about race may be sensitive to the methodology used.

While research on the impact of welfare benefits on family formation decisions has often used cross-state variation to identify the effect of welfare, as noted above, a positive crosssectional correlation between welfare and single headship may reflect a state's tolerance for single parent households and other unmeasured factors rather than a causal effect of welfare. ${ }^{7}$ This has led to the adoption in recent work by Moffitt (1994) and Hoynes (1997) of a fixed effects methodology that relies on changes in welfare benefit levels in a state as a potential cause of changes in single headship. In both of these studies, welfare effects on single parenthood were found to be stronger for blacks than whites. But Hoynes (1997) points out that if, in a panel data source such as the Panel Study of Income Dynamics (PSID), the composition of state populations change over time through migration of individuals and sample attrition or entry, then the state fixed effects specification may still yield spurious results. This leads her to include individual as well as state fixed effects in some of her specifications.

In implementing the individual and state fixed effects design, Hoynes (1997) finds that the positive effect of welfare on single headship obtained in the state fixed effect specification disappears. This finding could mean that the positive effect in models that control only for fixed state effects was spurious. As Hoynes (1997) points out, the only mechanisms through which 
adding individual fixed effects to the state fixed effects model could influence the welfare coefficient are through migration or through compositional changes over time in the PSID sample within states. Specifically, if no one moved and no one left or joined the panel after the first year, then state fixed effects and individual fixed effects would provide the same information. ${ }^{8}$ Since only 9 percent of blacks and 16 percent of whites ever migrated in the 21 year period in Hoynes' data, one is potentially placing a lot of weight on a relatively small number of people (the migrants, as well as sample attriters or joiners) in concluding that welfare has no effect on family formation. ${ }^{9}$

The research design pursued here uses three consecutive independent cross sections from the 1970, 1980 and 1990 Censuses to examine the impact of welfare on family formation outcomes by taking into account MSA fixed effects and MSA-specific time trends. As discussed above, the latter occur when norms and other trending forces are changing at different rates in different areas, while the earlier literature on welfare has assumed that these forces are fixed. Since we do not have a panel of individuals, we cannot know specifically whether any changes in single parenthood or in its rate of change are due to the behavior of migrants or current residents. However, by examining the characteristics of migrants, we can make some inferences about what may be driving the changes in single parenthood and headship.

In an earlier paper, Blau, Kahn, and Waldfogel (2000), we examined the determinants of marriage. We found that in fixed effects (first difference) models estimated over the 1980-90 period, welfare had significantly negative effects on marriage for less educated young black and white women. These effects were larger in magnitude for blacks, similar to the fixed effects

\footnotetext{
${ }^{7}$ Again, Ellwood and Bane (1985) were among the first to draw attention to this issue.

${ }^{8}$ In the models that control for state and individual fixed effects, the state fixed effects could reflect the possibility that individuals' tastes come to resemble those in the state where they live.

${ }^{9}$ We return to the issue of welfare and migration below.
} 
results for single headship in Hoynes (1997), and as mentioned earlier, some of the findings in Moffitt (1994). However, when we took account of heterogeneity in time trends by using second differences, the effects of welfare became small in magnitude and statistically insignificant, suggesting a correlation between trends in norms and other trending forces and trends in welfare benefits. ${ }^{10}$

In order to estimate the effects of welfare on single parenthood and headship, we need to take into account labor and marriage market conditions, including the supply of marriageable men. Several previous studies have found that men's employment opportunities have a positive effect on marriage for both blacks and whites. ${ }^{11}$ However, the same considerations that led some researchers to use fixed effects models in estimating the effects of welfare apply here. For example, married men outearn single men (Korenman and Neumark 1991), suggesting that the high marriage rates one observes in areas with good male job opportunities may merely reflect married men's greater productivity. And our reasoning about time trends applies here as well: improvements in married men's job opportunities may reflect secular changes in married men's wage premium. Again, models with area-specific time trends (in addition to fixed effects) can in principle take account of such effects.

A common shortcoming of the literature on family formation is that studies have tended to use a fairly limited measure of labor market conditions (typically, the unemployment rate and/or average earnings). Moreover, previous studies have tended to measure labor market conditions for all men or women rather than by education and race groups separately. Much of this earlier work uses actual female and male wage or employment rates as explanatory variables, even though these

\footnotetext{
${ }^{10}$ Papers by Ribar and Wilhelm (1999) and Page, Spetz, and Millar (2000) on welfare caseloads also find that it is important to control for time trends.

11 See, for example, Olsen and Farkas 1990; Fitzgerald 1991; Mare and Winship 1991; Lichter, LeClere, and McLaughlin 1991; Schultz 1994; Wood 1995; Brien 1997; Blau, Kahn, and Walfogel 2000.
} 
will be affected by marriage and fertility decisions. Further, measures of the supply of marriageable men generally combine the effects of partner availability and labor market conditions into one measure. This study differs from previous research in using a richer and plausibly more exogenous set of measures of labor and marriage market conditions, and in using measures that are disaggregated by education and race groups. These measures are described in detail below.

A final distinctive feature of our research design is to focus on young women — those aged 16-24. This means that we are measuring labor market conditions at roughly the time when these women are making their family formation decisions. Including older age groups, as much of the existing work does, brings in groups who made their family formation decisions at widely-varying times, hence possibly under widely differing labor and marriage market conditions. Our focus on young women also means that we are concentrating on the age group that has been at the center of much of the policy concern. Of course it must be acknowledged that our results may not be representative of the behavior of women outside our age group.

\section{Analytical Framework, Data and Methodology}

This study exploits MSA-level differences in welfare policy and labor and marriage market conditions to estimate the impact of these factors on young women's propensity to become single parents or single heads. The analytical framework is based on the assumption that substitution in the labor market between groups such as high school dropouts or college graduates is imperfect. Thus, changes in relative supply of or demand for such groups will in general produce changes in relative wage offers (Katz and Murphy 1992). These in turn are expected to affect family formation decisions. As discussed above, labor and marriage market conditions are expected to have theoretically ambiguous effects on the incidence of single 
motherhood and single headship, due to opposing effects on being single and having children.

We use metropolitan areas to test the impact of welfare benefits because the geographic extent of labor markets is better described by metropolitan areas than by states. Of course, to implement such a strategy, one needs a theory of regional labor markets. In formulating this framework, our maintained hypothesis is that supply and demand adjustments across regions are partially limited by mobility costs. A considerable body of research supports this view, finding that demand or supply shifts have wage or employment-to-population ratio effects that last up to 10-15 years (Bartik 1993, 1994; Topel 1986, 1994; Bound and Holzer 1993 and 2000; Borjas and Ramey 1995). ${ }^{12}$

To analyze family formation outcomes, we use microdata on women age 16-24 from the five percent samples of the 1980 and 1990 Censuses and the two percent sample of the 1970 Census. These are the largest available samples in each year. While macroeconomic conditions were fairly similar in the latter two years, 1970 was a mild recession year. We exploit area differences in economic activity as important explanatory variables, providing some control for economic conditions. The Census files contain sufficient observations to stratify analyses by race-education group and to identify local labor market effects within each of these categories. Our local labor markets are MSAs. Where boundaries for MSAs change over time, we use a consistent set of definitions so that comparable areas are defined for 1970, 1980 and $1990 .^{13}$ Due to sample size considerations, we use 67 comparable MSAs which have at least ten young women in each race-education subgroup across which our supply and demand indexes are

${ }_{12}$ However, Blanchard and Katz (1992) argue that migration undoes regional demand effects within a decade.

${ }^{13}$ Because of changing definitions, these MSAs were created by matching as closely as possible the metropolitan areas as defined by the Census. We were guided by Bound and Holzer's (2000) original breakdown of these areas. In some cases, MSAs were consolidated so that we only know the probability that an individual is in a particular MSA. When this relatively rare event occurred, we included individuals only if they had a greater than .5 probability of living in a particular MSA, and we assigned them to this MSA. See the Appendix for further details. 
defined (see below).

In this paper, we use all blacks and all whites regardless of Hispanic ethnicity status.

This decision was necessitated by the fact that Hispanics were not separately identified in the 1970 Census. For the purposes of creating labor and marriage market variables (see below), we also divide our samples of young women into three education groups: those with less than a high school education; those who have completed high school but have no further education; and those who have completed some college beyond high school (this latter category includes both those with some college and those with a college degree). In some analyses, we estimate separate equations for the less educated group because we expect welfare to have larger effects for them than for the whole population.

A single mother is defined as a woman who is not currently married and who is coded by the Census as the mother of children under 18 living in the household. ${ }^{14}$ A single head is defined as a single mother who is also head of the household. The analysis uses microdata on individuals to estimate the impact of welfare benefits on family formation. The following probit model for the determinants of single motherhood (headship) for person $i$, in metropolitan area $j$ and year $t$ is estimated separately by race:

(1) $\mathrm{P}\left(\mathrm{Y}_{\mathrm{ijt}}=1\right)=\Phi\left(\mathrm{V}_{\mathrm{ijt}} \mathrm{b}_{\mathrm{t}}+\mathrm{C}_{\mathrm{jt}} \mathrm{W}\right)$, where $\mathrm{Y}$ is a dummy variable signifying that one is a single mother (head), $\Phi(-)$ is the standard

\footnotetext{
${ }^{14}$ It is important to note that the 1970 and 1980 Censuses undercount single mothers living in subfamilies. (For an extensive discussion of this problem, see Ellwood and Bane 1985; see also London 1998.) To correct the undercount, we create our own variable for single mother in a subfamily, following Ellwood and Bane (1985), by matching any child identified as a "grandchild of the head" in the 1970 or 1980 Census to a single young woman living in the household if she is the daughter of the head and is at least 15 years older than the child. We do not analyze separately those single parents who are cohabiting because we cannot identify cohabiting couples with certainty in the Census. Thus, we follow in the tradition of the literature on welfare effects of simply distinguishing married couple from single parent families. For a recent analysis of the effects of welfare on cohabitation decisions, see Moffitt, Reville, and
} 
normal cumulative distribution function, $\mathrm{V}$ is a vector of individual characteristics, $\mathrm{C}$ is a vector of MSA-specific factors, and $\mathrm{b}$ and $\mathrm{w}$ are coefficient vectors.

In the vector $\mathrm{V}$, we control for measured characteristics available in the census data which would be expected to affect an individual's labor market prospects, their attractiveness as a marriage partner, and their preferences regarding marriage and motherhood. Thus, although our age group is relatively narrow, we take advantage of the large sample sizes available in the Census to include individual age dummy variables in years, as well as schooling dummy variables referring to different levels of schooling. Specifically, we include controls for the following educational categories: 0 years completed, 1-4 years, 5-8 years, 9 years, 10 years, 11 years, 13-15 years and 16 years and over. The omitted category is those with exactly twelve years completed. ${ }^{15}$

We include those enrolled as well as those not enrolled in school because schooling decisions are made in the same context as marriage and childbearing decisions. Thus, in effect we estimate reduced form models for single parenthood and headship. While we acknowledge that the education variable may be endogenous, we also believe that it is especially important to control for this in analyzing the impact of welfare, as has virtually every study of the impact of welfare. Since our samples are young and include the enrolled, the within-group control for age is important: the meaning of having less than a high school education, for instance, is not the same for someone age 16 (who may be continuing on) as it is for someone age 22 (who has likely completed her education). Our inclusion of individual age dummy variables controls for cross-MSA differences in the age composition of the population and thus allows for an

\footnotetext{
Winkler (1998).

${ }^{15}$ In calculating years of education, we follow Jaeger (1997) to deal with the changes that were made to the education questions beginning in the 1990 Census.
} 
appropriate interpretation of the coefficients on the MSA-level variables (C).

In the vector $\mathrm{C}$, we include a measure of welfare generosity which is of course the key explanatory variable of interest. Welfare benefit levels are measured as the log of the sum of 0.7 times the maximum AFDC benefit plus food stamp benefits available for a family of four in the state in which the MSA is located in 1980 dollars. ${ }^{16}$ We also include the following MSA-level control variables: the adult male (ages 25-54) unemployment rate and the log of the adult male average wage level in the labor market as measures of overall indicators of labor market conditions. Further, controlling for wage levels puts a sharper interpretation on the welfare benefit variable, since average hourly wages are likely to be closely correlated with local living costs. In addition, adult wages and unemployment are less likely to be endogenous to the behavior of the younger age group employed in our primary analyses than measures which include younger individuals. Wages were expressed in 1980 dollars and computed as the previous year's annual earnings divided by the product of weeks worked and average weekly work hours among the nonself-employed. ${ }^{17}$

Finally in each model, we include indexes (defined below) of labor market demand and supply for young men and young women in each of twelve race-gender-education groups of 1624 year olds: (white, black) $x$ (male, female) $\mathrm{x}(\mathrm{ED}<12, \mathrm{ED}=12, \mathrm{ED}>12)$. Since we use estimates of the underlying supply and demand conditions that determine wage and employment

\footnotetext{
${ }^{16}$ We use .7 times the maximum AFDC benefit to add to food stamps because AFDC had a benefit reduction rate of .3 with respect to food stamps (Moffitt 1994). In some cases, an MSA spanned more than one state. In such cases, the welfare benefit variable was a population-weighted average of the indicated states' benefit levels. Hutchens, Jakubson, and Schwartz (1989) also note that the difference between the benefits one is eligible for in an extended family vs. heading one's own household should affect living arrangements. The authors used a telephone survey of state agencies to collect data on this difference at one point in time (the mid 1980s). However, such data are not available on the time series basis necessary to use in our analyses. We note, however, that Hutchens, Jakubson, and Schwartz find for all states that it was easier to qualify for benefits as a household head than as a single mother in an extended family. Thus, our welfare benefit variable should at least be positively correlated with the gains to being a single mother household head.

${ }^{17}$ Those with computed hourly wages less than $\$ 1$ or greater than $\$ 250$ in 1980 dollars were excluded from the
} 
opportunities, rather than the actual earnings and employment of the young women and their potential partners as explanatory variables, our approach is less likely to be contaminated by reverse causality biases than much previous work. Each equation has twelve supply variables and twelve demand variables, and the model thus allows supply and demand for a given group (for example, black men with 12 years of schooling) to influence the family formation decisions of each of the race-education groups of women studied here. Taken together, the demand and supply indexes control for the underlying determinants of each group's labor market prospects as well as the pure supply of potential partners. We followed the approach of including the full set of supply and demand variables for each observation because it did not in any way constrain the coefficients on the supply and demand variables or require us to make any a priori assumptions about likely marriage patterns. ${ }^{18}$

A group's supply and demand indexes are defined as:

(2) Supply $_{\mathrm{kjt}}=\ln \left(\mathrm{S}_{\mathrm{kjt}}\right)$

(3) $\operatorname{Demand}_{\mathrm{kjt}}=\ln \left(\mathrm{D}_{\mathrm{kjt}}\right)$,

where $\mathrm{k}$ stands for gender-education-race group of 16-24 year olds, $\mathrm{j}$ for MSA, $\mathrm{t}$ for year, $\mathrm{S}_{\mathrm{kjt}}$ is

calculations.

${ }^{18}$ In earlier work (Blau, Kahn and Waldfogel 2000), we defined "net labor market supply" as the difference between each group's supply and demand indexes and used this variable as the indicator of labor market conditions for the group. We also assumed assortive mating, that is that young women would be most likely to marry young men in their age and education group. Under these assumptions, labor and marriage market conditions for a raceeducation group could be summarized by three variables: net labor market supply for women in the race-education group; net labor market supply for men in the race-education group; and net marriage market supply of young women in the race-education group (equal to the difference between the supply indexes of young men and women in the race-education group). Preliminary results were similar to those reported below when we followed this approach here. 
the fraction of the MSA's total population comprised by group $\mathrm{k}$, and $\mathrm{D}_{\mathrm{kjt}}$ is a demand index in year $\mathrm{t}$ for group $\mathrm{k}$. The demand indexes are similar to those constructed by Katz and Murphy (1992) and are defined as follows:

(4) $\mathrm{D}_{\mathrm{kjt}}=\Sigma_{\mathrm{o}}\left(\mathrm{s}_{\mathrm{okt}} * \mathrm{E}_{\mathrm{ojt}} / \mathrm{E}_{\mathrm{jt}}\right)$,

where o indexes industry-occupation category (14 industries crossed with 3 occupations), ${ }^{19} \mathrm{~S}_{\mathrm{okt}}$ is the share that group k comprises of total US employment in industry-occupation cell o; and $\mathrm{E}_{\mathrm{ojt}}$ and $\mathrm{E}_{\mathrm{jt}}$ are respectively MSA $\mathrm{j}$ employment in industry-occupation cell o and total MSA $\mathrm{j}$ employment.

The demand index is essentially a predicted MSA employment share for group $\mathrm{k}$ in MSA $\mathrm{j}$, where we weight the relative employment of industry-occupation group o in area $\mathrm{j}$ by the national importance of group $\mathrm{k}$ in the industry-occupation cell. Since the same weights $\left(\mathrm{s}_{\mathrm{ok}}\right)$ are used for each MSA in a given year, the demand index is driven by area differences in overall industry-occupation composition of employment. The supply index is the group's actual population share which is thus in similar units as the predicted employment share in the demand index.

Of course, these demand and supply indexes may be affected by relative wages and are therefore not precisely the same as the desired notion of the placement of the local relative demand and supply curves (Katz and Murphy 1992). However, since the demand index is based

\footnotetext{
${ }^{19}$ The industry categories are: Agriculture, Forestry and Fisheries; Mining; Construction; Manufacturing (Durable Goods); Manufacturing (Nondurable Goods); Transportation, Communications and Other Public Utilities; Wholesale Trade; Retail Trade; Finance, Insurance, and Real Estate; Business and Repair Services; Personal Services Including Private Households; Entertainment and Recreation Services; Professional and Related Services; and Public Administration. The three occupation groups are: Professional, Technical and Managerial; Clerical and Sales; Craft, Operative, Laborer and Service.
} 
on national employment shares for the group in each industry-occupation cell and overall local employment in each industry-occupation cell, it is not likely to be greatly affected by changes in our focal groups' local wage levels. Furthermore, the supply index refers to population rather than employment shares, again providing perhaps a more convincing source of exogenous variation, although even the population of a given race-gender-education group may be affected by relative wages through migration and schooling decisions. ${ }^{20}$

Equation 1 is estimated on a pooled 1970-1980-1990 sample with MSA dummy variables, MSA-specific time trends, ${ }^{21}$ and overall time effects. We compute Huber-White standard errors and allow for correlation of the errors within each MSA. ${ }^{22}$ In each of the models, we allow the coefficients of the individual-specific variables to be different in different time periods by interacting them with the year dummy variable(s).

\section{Results}

\section{A. Sample Means}

Table 1 shows sample means of the dependent variables for the underlying 1970, 1980 and 1990 Census microdata for the 67 MSAs upon which our regression analysis is based. (Table A1 contains a list of the MSAs.) While our 67 MSAs constitute only a subset of the population, national means are virtually identical to those reported in Table $1 .^{23}$ The data in Table 1 reflect some well-known national patterns. In each year, black women are considerably

\footnotetext{
${ }^{20}$ The demand index as defined above uses employment shares and the current year national employment share weights. Our results were the same when we used shares of work hours instead of employment.

${ }_{21}$ The MSA-specific time trends are equal to the MSA dummy variables multiplied by YEAR, where YEAR=1970, $1980,1990$.

${ }^{22}$ We used the probit routine in STATA, allowing for clustering of the errors by MSA.

${ }^{23}$ Our 67 MSA sample was determined by our ability to match MSAs across the three census years and also to obtain a sufficient number of observations on each race-education group in the MSA (that is, ten for each raceeducation group). The pooled 1970-1980-1990 MSA sample included 60.9 percent of the national population for
} 
more likely to be single mothers and single heads than are white women. The data also show an increase in the incidence of single motherhood and single headship for both blacks and whites over the 1970-90 period taken as a whole, although, especially for blacks, there was some leveling off in the trends over the 1980s.

At the aggregate level, it is difficult to attribute the observed increases in single motherhood to welfare benefits, since benefits declined by an average of about 18 percent in real terms in our MSA sample between 1970 and 1980, and fell by 9 percent between 1980 and 1990 . Thus not only have welfare benefits been falling during this period of rising single motherhood; they fell faster during the period when this outcome was increasing fastest for black women. It is still possible, however, for welfare benefits to be a determinant of single motherhood, and our regression analyses attempt to estimate this effect.

\section{B. Basic Probit Regression Results}

The probit results for the welfare benefit variable are presented in Tables 2 (white women) and 3 (black women). The entries are the partial derivative of the dependent variable with respect to the welfare benefit measure evaluated at the mean of the dependent variable. The Tables present results for cross-sectional models (Panel A), models with MSA dummies (Panel B), and models with MSA dummies and MSA-specific trends (Panel C). For purposes of comparison, within each Panel, we present models for all women and for those with less than 12 years of schooling. We also report results for two specifications: models with the adult male log wage and unemployment rate included, and models with these two indicators plus our 24 supply and demand variables.

Despite the large number of specifications, some general patterns emerge. First, in the 
cross-sectional models (Panel A of Tables 2 and 3), welfare has positive coefficients for both single motherhood and single headship for whites and blacks. Moreover, these effects are significant in each case for whites and for single headship for blacks. The estimated derivatives tend to be larger for the less educated than for the full sample, although the differences are not large among blacks. Thus, the results indicate that without taking into account MSA fixed effects or trends, it appears that welfare encourages single motherhood for whites and single headship for both whites and blacks.

When we add MSA fixed effects (Tables 2 and 3, Panel B), the positive effects for whites all become negative, with several of them statistically significant. The single motherhood results for blacks remain insignificant and usually positive, while the black single headship results remain positive, with two of them marginally significant-all education groups pooled with the full set of labor market variables, and the less educated with just adult male wages and unemployment included. These results are qualitatively similar to previous findings using state fixed effects that found a welfare effect on single headship only among blacks (Moffitt 1994 in one specification; Hoynes 1997).

Finally, we turn to the results which take into account both MSA fixed effects and MSAspecific trends (Tables 2 and 3, Panel C). These specifications continue to show no evidence of positive welfare effects for whites. In the second model shown (that is, with the full set of labor market variables), the effects of welfare for whites are insignificant three times and significantly negative once (single motherhood, education < 12). As mentioned earlier, Moffitt (1990) has pointed out that in some studies welfare has been found to have negative effects on single headship, a seemingly counterintuitive finding. In any event, for whites at least, carefully controlling for omitted variables by including MSA dummies and trends eliminates the 
apparently positive effects of welfare found in the cross-sectional results (Table 2, Panel A).

For young black women, when we control for MSA dummies and trends (Table 3, Panel C), welfare continues to have insignificant effects on single motherhood. However, when we control for the full set of labor market variables, welfare has positive and significant effects on single headship for black women overall and for less educated black women. In these fullyspecified models, the derivatives are 0.081 (asymptotic standard error 0.044 ) for the full black sample and 0.119 (asymptotic standard error 0.057 ) for less educated black women. At the mean frequency of single headship for each group, these derivatives correspond to elasticities of 0.871 for the full sample and 1.312 for those with education less than 12 years. This pattern of elasticities is consistent with our expectation that welfare would have larger effects for those with lower potential market wages, as is the fact that welfare has more a positive effect on black than white women (due to black women's lower income levels). In sum, for black women in general and especially for less educated blacks, these results imply that while welfare raises the likelihood that single mothers will form their own households, it does not raise the incidence of single motherhood itself. As noted above, this is one of the most robust results in the prior literature on the effects of welfare on demographic outcomes. The larger size and significance of the coefficients when the group-specific supply and demand variables are included suggests the importance of taking into account group-specific indicators of labor market conditions, rather than simply aggregate indicators.

While we have found some evidence that, for young black women, welfare benefits are positively associated with single headship, the Census data do not allow us to determine whether this effect is due to the family formation decisions of women who live in a particular area or the attraction of single heads to high benefit areas. This ambiguity characterizes all research that 
uses single cross-sections or pooled cross sections such as multiple years of the Census or the Current Population Survey, and is present to some extent even in Hoynes' (1997) panel date model including both individual and state effects. In the latter case, while we do know whether the dependent variable, single headship, has changed for the individual, a positive effect of welfare benefits on single headship could still reflect either a change in headship in response to welfare benefit levels after an exogenous move or a prior decision to become a single head and hence move to a high benefit state. Thus, short of a multiequation model of migration and family formation, which would be extremely hard to credibly identify, we cannot, even with panel data, definitively resolve the migration issue.

Although we cannot say whether our results reflect the impact of welfare benefits on residents' decisions to be single heads or on single heads' propensity to move to high benefit states, we can at least shed some light on the dimensions of this problem of interpretation. We note first that, among the 16-24 year old black women in our regression samples, giving 1970, 1980 and 1990 equal weight, only 11.2 percent had migrated in the last five years. The corresponding figure for those with less than 12 years of schooling was an even smaller migration rate of 7.8 percent. The low incidence of migration places some sharp limits on the degree to which the behavior of migrants could be explaining our results. Second, for the full sample of young black women, the incidence of single headship was 8.8 percent among nonmigrants and a roughly similar 7.7 percent for migrants, with corresponding figures for the lesseducated of 8.4 percent among non-migrants and 9.4 percent among migrants, again weighting the 1970, 1980 and 1990 samples equally. This similarity in the incidence of single headship among migrants and nonmigrants in conjunction with the small number of migrants suggest that migration is unlikely to account for our welfare results. 


\section{Supplementary Results}

While our focus in this paper is the impact of welfare on family formation decisions, it is also of some interest to consider the impact of the personal characteristics and labor market variables. Selected results for these variables for the incidence of single headship are shown in Table 4 for the specification that includes MSA dummies and MSA trends. The age and education results reported in the Table are the estimated main effects of these variables. They measure the impact of these variables for 1970, since the equations also include age and education interactions with 1980 and 1990 dummy variables. The main effects indicate that, as would be expected, the incidence of single headship rises with age (the omitted category is age 24) and falls with education level (the omitted category is ed 12), all else equal. Our findings for the interactions of these variables with the year dummies, which are not shown in the Table, indicate that the incidence of single headship in 1980 and 1990 fell relative to 1970 for the very young (ages 16 and 17) and for those with some college education. These latter findings for education are consistent with results reported by Blau (1998), who found that the relationship between single parenthood and education became more negative over this period.

The coefficients for the 24 group-specific supply and demand variables are highly significant as a group. When these variables are excluded, the overall labor market indicators (adult male log wages and unemployment) are jointly significant and indicate that higher overall wages and lower overall unemployment are negatively associated with single headship for whites and blacks. However, when we add the supply and demand variables, the overall wage and unemployment effects become insignificant individually and jointly. Perhaps the groupspecific supply and demand variables capture labor and marriage market conditions more accurately than the overall labor market indicators (wage and unemployment levels) that most 
previous research has employed.

\section{Alternative Specifications}

In addition to the specifications shown in Tables 2 and 3, we found that the basic results for welfare benefits were robust to a variety of alternative specifications. First, in addition to the regular AFDC and food stamps programs, in 198025 states plus Washington DC offered AFDC in some cases to married-couple families through the AFDC-Unemployed Parent (AFDC-UP) program. $^{24}$ The Family Support Act of 1988 required all states to offer AFDC-UP by October 1990, and they all did. But we do not know whether they began offering it by the spring of 1990 when the Census interviews were conducted. Despite this ambiguity in the timing of AFDC-UP coverage, we estimated supplementary models with a dummy variable for AFDC-UP coverage as of 1970,1980 or 1988 for the corresponding regressions. The findings for welfare benefit levels are very similar to those without controlling for AFDC-UP coverage.

Second, our models with MSA fixed effects and MSA-specific trends are an attempt to account for otherwise unmeasured variables and their trends that could affect both welfare benefits and family formation decisions. Yet even controlling for such trends may not adequately account for unmeasured variables that could bias even the second difference equations. We attempted to control for such factors by adding to some specifications variables reflecting the political climate in each state. Specifically, we include: the fraction of the state's lower house comprised of Democratic party members; the fraction of the upper house that was Democratic; and an indicator variable for whether the governor was Democratic. ${ }^{25}$ When these variables were added, the results for the welfare benefit variable were virtually identical to those

24 This description of the AFDC-UP is based on data generously provided to us by Hilary Hoynes.

25 As with the welfare benefit variable, when an area spanned more than one state, the political variables were computed as the population-weighted averages across the relevant states. 
reported in Tables 2 and 3, giving us further confidence that we have adequately controlled for omitted variables.

\section{Conclusions}

This paper has used data from the 1970, 1980 and 1990 Censuses to investigate the impact of welfare benefits on the incidence of single parenthood and headship for young women. We controlled for personal characteristics, labor and marriage market conditions, and unlike most previous research on the impact of welfare, metropolitan area fixed effects and MSA-specific time trends. The importance of controlling for MSA fixed effects and trends is that area-specific factors such as norms or other unmeasured economic or social factors and their trends may affect both the provision of welfare benefits and individual family formation decisions. The large sample size of the Census also allows us to control for labor and marriage market conditions in a more detailed way than in previous work. Stratifying by race, we estimated the impact of welfare benefits on single motherhood and single headship for individuals overall and separately for the less educated, a group we expect to be disproportionately affected by welfare.

Consistent with earlier research on the impact of welfare, we find positive cross-sectional associations between welfare benefits and single parenthood and headship. However, these crosssectional associations may reflect unmeasured factors such as norms that influence single parenthood or headship and welfare benefits levels. Similar to results obtained in recent studies by Moffitt (1994) and Hoynes (1997), using data other than the Census, we find some evidence that the positive effects on single headship remain for black women but largely disappear for whites when MSA fixed effects are included. However, even a specification including such MSA fixed effects does not account for unmeasured factors such as changing norms and other trending forces that 
cause changing levels of both welfare benefits and single headship. The use of three waves of Census data enables us to account for these factors by including MSA-specific time trends. In these analyses, a positive effect of welfare benefits on single headship for young black women and an even larger positive effect for young less educated black women remains. We conclude that for young black women, curtailing welfare benefits may well raise the likelihood that single mothers live in extended family arrangements but without affecting the likelihood that they become single mothers in the first place. This might be expected to benefit children who may be more likely to live with multiple adult relatives than otherwise, but much depends on the circumstances of the individual family (Moore and Brooks-Gunn, 2002). Regardless of its effect on child well-being, a reduction in single headship, rather than single motherhood itself, is clearly not the main outcome that welfare reformers had in mind when they enacted the federal reforms of 1996, and the state reforms that preceded them. Our results regarding single parenthood confirm those of much of the earlier literature: welfare benefits seem not to be an important motivator for young women to have children out-of-wedlock. 


\section{References}

Bartik, Timothy J. 1993. "Who Benefits from Local Job Growth: Migrants or the Original Residents?" Regional Studies 27(4): 297-311.

Bartik, Timothy J. 1994. "The Effects of Metropolitan Job Growth on the Size Distribution of Family Income." Journal of Regional Science 34 (4): 483-501.

Becker, Gary S. 1981. A Treatise on the Family. Cambridge, MA: Harvard University Press.

Blanchard, Olivier, and Lawrence F. Katz. 1992. "Regional Evolutions.” Brookings Papers on Economic Activity No. 1: 1-61.

Blank, Rebecca M. 1997. "Policy Watch: The 1996 Welfare Reform.” Journal of Economic Perspectives 11(3): 169-77

Blau, Francine D. 1998. "Trends in the Economic Well-Being of Women: 1970-1995," Journal of Economic Literature 36(1): 112-165.

Blau, Francine D., Lawrence M. Kahn, and Jane Waldfogel. 2000. "Young Women's Marriage Rates in the 1980s: The Role of Labor and Marriage Market Conditions." Industrial \& Labor Relations Review 53(4): 624-647.

Borjas, George J., and Valerie Ramey. 1995. "Foreign Competition, Market Power, and Wage Inequality." Quarterly Journal of Economics 110(4): 1075-1110.

Bound, John, and Harry Holzer. 1993. "Industrial Shifts, Skills Levels, and the Labor Market for White and Black Males." The Review of Economics and Statistics 75(3): 387-396.

Bound, John, and Harry Holzer. 2000. "Demand Shifts, Population Adjustments, and Labor Market Outcomes during the 1980s." Journal of Labor Economics 18(1): 20-54.

Brien, Michael J. 1997. "Racial Differences in Marriage and the Role of Marriage Markets." Journal of Human Resources 32(4): 741-78.

Danziger, Sheldon, George Jakubson, Saul Schwartz, and Eugene Smolensky 1982. "Work and Welfare as Determinants of Female Poverty and Female Headship.” Quarterly Journal of Economics 97(3): 519-534.

Darity, William A., Jr., Samuel L. Myers, and Phillip Bowman. 1995. "Family Structure and the Marginalization of Black Men: Policy Implications." In The Decline in Marriage Among African-Americans: Causes, Consequences and Policy Implications, eds. M. Belinda Tucker and Claudia Mitchell-Kernan, 263-308. New York, NY: Russell Sage Foundation.

Ellwood, David, and Mary Jo Bane. 1985. "The Impact of AFDC on Family Structure and Living Arrangements." Research in Labor Economics 7: 137-207. 
Ellwood, David, and Jonathan Crane. 1990. "Family Change among Black Americans: What Do We Know?" Journal of Economic Perspectives 4(4): 65-84.

Fitzgerald, John. 1991. "Welfare Durations and the Marriage Market: Evidence from the Survey of Income and Program Participation." Journal of Human Resources 26(3): 545561.

Hoynes, Hilary Williamson 1997. "Does Welfare Play Any Role in Female Headship Decisions?" Journal of Public Economics 65(2): 89-117.

Hutchens, Robert M., George Jakubson, and Saul Schwartz. 1989. "AFDC and the Formation of Subfamilies." Journal of Human Resources 24(4): 599-628.

Hu, Wei-Yin. 2001. "Welfare and Family Stability: Do Benefits Affect When Children Leave the Nest?” Journal of Human Resources 36(2): 274-303.

Jaeger, David. 1997. "Reconciling the Old and New Census Bureau Education Questions: Recommendations for Researchers." Journal of Business and Economic Statistics 15(3): 300-309.

Katz, Lawrence F., and Kevin M. Murphy. 1992. "Changes in Relative Wages, 1963-1987. Supply and Demand Factors." Quarterly Journal of Economics 107(1): 35-78.

Korenman, Sanders, and David Neumark. 1991. "Does Marriage Really Make Men More Productive?" Journal of Human Resources 26(2): 282-307.

Lichter, Daniel T., Felicia B. LeClere, and Diane K. McLaughlin. 1991. "Local Marriage Markets and the Marital Behavior of Black and White Women." American Journal of Sociology 96(4): 843-867.

London, Rebecca. 1998. "Trends in Single Mothers' Living Arrangements From 1970 to 1995: Correcting the Current Population Survey". Demography 35(1): 125-131.

Mare, Robert D., and Christopher Winship. 1991. "Socioeconomic Change and the Decline of Marriage for Blacks and Whites." In The Urban Underclass, eds. Christopher Jencks and Paul E. Peterson, 175-202. Washington, D.C.: Brookings Institution.

McLanahan, Sara, and Gary Sandefur. 1994. Growing Up with a Single Parent: What Hurts, What Helps? Cambridge, Mass: Harvard University Press.

Moffitt, Robert. 1990. "The Effect of the U.S. Welfare System on Marital Status." Journal of Public Economics 41(1): 101-124.

Moffitt, Robert. 1992. "Incentive Effects of the U.S. Welfare System: A Review." Journal of Economic Literature 30(1): 1-61.

Moffitt, Robert. 1994. "Welfare Effects on Female Headship." Journal of Human Resources 29(2): 621-636. 
Moffitt, Robert. (1998). "The Effect of Welfare on Marriage and Fertility: What Do We Know and What Do We Need to Know?" In Welfare, the Family, and Reproductive Behavior: Research Perspectives, ed. Robert Moffitt, 50-97. Washington, D.C.: National Research Council.

Moffitt, Robert, Robert Reville, and Anne E. Winkler. 1998. "Beyond Single Mothers: Cohabitation and Marriage in the AFDC Program." Demography 35(3): 259-278.

Moore, Mignon R., and Jeanne Brooks-Gunn. (2002). "Adolescent Parenthood." In Handbook of Parenting, vol. 4, ed. M. Bornstein, 173-214. Mahwah, NJ: Lawrence Erlbaum \& Associates.

Olsen, Randall J., and George Farkas. 1990. "The Effect of Economic Opportunity and Family Background on Adolescent Cohabitation and Childbearing among Low Income Blacks." Journal of Labor Economics 8(3): 341-362.

Page, Marianne E., Joanne Spetz, and Jane Millar. 2000. "Does the Minimum Wage Affect Welfare Caseloads?” Joint Center for Poverty Research Working Paper 135, (January).

Ribar, David C., and Mark Wilhelm. 1999. "The Demand for Welfare Generosity." Review of Economics and Statistics 81(1): 96-108.

Schultz, T. Paul. 1994. "Marital Status and Fertility in the United States: Welfare and Labor Market Effects." Journal of Human Resources 29(2): 636-669.

Topel, Robert. 1986. "Local Labor Markets.” Journal of Political Economy 94(3, Part 2): S111-S143.

Topel, Robert. 1994. "Regional Labor Markets and the Determinants of Wage Inequality." American Economic Review 84(2): 17-22.

Wilson, William Julius. 1987. The Truly Disadvantaged. Chicago, IL: University of Chicago Press.

Winkler, Anne E. 1992. "The Impact of Housing Costs on the Living Arrangements of Single Mothers." Journal of Urban Economics 32(3): 388-403.

Wood, Robert G. 1995. "Marriage Rates and Marriageable Men: A Test of the Wilson Hypothesis." Journal of Human Resources 30(1): 163-193. 
Table 1: Mean Values for the Regression Sample

\begin{tabular}{rcccc}
\hline & \multicolumn{2}{c}{ Whites } & \multicolumn{2}{c}{ Blacks } \\
\cline { 2 - 5 } & $\begin{array}{c}\text { Single } \\
\text { Motherhood }\end{array}$ & $\begin{array}{c}\text { Single } \\
\text { Headship }\end{array}$ & $\begin{array}{c}\text { Single } \\
\text { Motherhood }\end{array}$ & $\begin{array}{c}\text { Single } \\
\text { Headship }\end{array}$ \\
\hline 1970 & 0.025 & 0.014 & 0.144 & 0.069 \\
1980 & 0.031 & 0.018 & 0.192 & 0.099 \\
1990 & 0.044 & 0.020 & 0.213 & 0.094 \\
All & 0.035 & 0.018 & 0.192 & 0.093 \\
$\mathrm{~N}$ & \multicolumn{2}{c}{674,649} & \multicolumn{2}{c}{163,984} \\
\hline
\end{tabular}

Notes A single mother is defined as a woman who is not currently married and who is the mother of a child or children under 18 living in the household. A single head is defined as a single mother who is also head of the household. 
Table 2: Derivatives for the Effect of Welfare Benefits Evaluated at Dependent Variable Mean: Whites (asymptotic standard errors in parentheses)

\begin{tabular}{lrrrr}
\hline & \multicolumn{3}{c}{$\begin{array}{c}\text { All Education Groups } \\
\text { Pooled }\end{array}$} & \multicolumn{2}{c}{ Education < 12 Only } \\
\cline { 2 - 5 } Specification & Single Mother & $\begin{array}{r}\text { Single } \\
\text { Head }\end{array}$ & Single Mother & $\begin{array}{r}\text { Single } \\
\text { Head }\end{array}$ \\
\hline
\end{tabular}

A. Cross Section

Adult Male Log Wages and

Unemployment Included

$\begin{array}{llcc}0.0083^{* *} & 0.0124^{* *} & 0.0184^{* *} & 0.0236^{* *} \\ (0.0037) & (0.0049) & (0.0083) & (0.0117)\end{array}$

Adult Male Log Wages and Unemployment and All Group Supply and Demand Indexes Included

$\begin{array}{llll}0.0100^{* * *} & 0.0114^{* * *} & 0.0185^{* * *} & 0.0214^{* * *} \\ (0.0031) & (0.0027) & (0.0046) & (0.0038)\end{array}$

B. MSA Dummies

Adult Male Log Wages and Unemployment Included

$\begin{array}{lccc}-0.0171^{* *} & -0.0107 & -0.0235 & -0.0227^{* *} \\ (0.0086) & (0.0088) & (0.0115) & (0.0159) \\ & & & \\ -0.0094 & -0.0045 & -0.0200^{*} & -0.0078 \\ (0.0067) & (0.0057) & (0.0104) & (0.0097)\end{array}$

Adult Male Log Wages and Unemployment and All Group Supply and Demand Indexes Included

C. MSA Dummies and MSA Trends

Adult Male Log Wages and Unemployment Included

$\begin{array}{lllr}-0.0166^{* *} & -0.0053 & -0.0345^{* * *} & -0.0094 \\ (0.0080) & (0.0056) & (0.0098) & (0.0098) \\ & & & \\ -0.0115 & 0.0047 & -0.0602^{* * *} & -0.0144 \\ (0.0105) & (0.0083) & (0.0214) & (0.0165)\end{array}$

Adult Male Log Wages and Unemployment and All Group Supply and Demand Indexes Included

Notes A single mother is defined as a woman who is not currently married and who is coded by the Census as the mother of children under 18 living in the household. A single head is defined as a single mother who is also head of the household. Coefficients are from probit models. Standard errors are heteroskedasticity-robust and are corrected for correlation within MSAs. Control variables include age and education dummies, whose effects are allowed to vary by year. Sample sizes are: Pooled=674,649; ED <12=227,144.

${ }^{* * *}$ Significantly different from zero at the 1 percent level on a two-tailed test.

** Significantly different from zero at the 5 percent level on a two-tailed test.

* Significantly different from zero at the 10 percent level on a two-tailed test. 
Table 3: Derivatives for the Effect of Welfare Benefits Evaluated at Dependent Variable Mean: Blacks (asymptotic standard errors in parentheses)

\begin{tabular}{|c|c|c|c|}
\hline \multirow[b]{2}{*}{ Specification } & \multirow{2}{*}{\multicolumn{2}{|c|}{$\frac{\text { All Education Groups Pooled }}{\text { Sinqle Mother Sinqle Head }}$}} & Education < 12 Only \\
\hline & & & Single Mother Single Head \\
\hline
\end{tabular}

A. Cross Section

Adult Male Log Wages and

Unemployment Included

$\begin{array}{rrrr}0.0189 & 0.0708^{* * *} & 0.0236 & 0.0827^{* * *} \\ (0.0258) & (0.0216) & (0.0307) & (0.0259)\end{array}$

Adult Male Log Wages and

Unemployment and All Group Supply and

Demand Indexes Included

$0.0200 \quad 0.0487^{* * *} \quad 0.02350 .0430$ *

$\begin{array}{llll}(0.0193) & (0.0175) & (0.0273) & (0.0221)\end{array}$

B. MSA Dummies

Adult Male Log Wages and

Unemployment Included

$\begin{array}{rrrr}0.0007 & 0.0519 & 0.0491 & 0.0800^{*} \\ (0.0462) & (0.0498) & (0.0463) & (0.0480)\end{array}$

Adult Male Log Wages and

Unemployment and All Group Supply and

Demand Indexes Included

$\begin{array}{rrrr}-0.0037 & 0.0483^{*} & 0.0100 & 0.0309 \\ (0.0360) & (0.0295) & (0.0476) & (0.0393)\end{array}$

C. MSA Dummies and MSA Trends

Adult Male Log Wages and

Unemployment Included

$\begin{array}{rrrr}-0.0050 & 0.0265 & 0.0149 & 0.0759 \\ (0.0588) & (0.0439) & (0.0584) & (0.0570)\end{array}$

Adult Male Log Wages and

Unemployment and All Group Supply and

Demand Indexes Included

$-0.0179 \quad 0.0812^{*}$

$(0.0443)$

0.0043

$0.1194^{* *}$

(0.0549)

$(0.0741)$

$(0.0567)$

Notes See notes to Table 2 for further explanation. Sample sizes are: Pooled=163,984; ED<12=67,952.

*** Significantly different from zero at the 1 percent level on a two-tailed test.

** Significantly different from zero at the 5 percent level on a two-tailed test.

* Significantly different from zero at the 10 percent level on a two-tailed test. 
Table 4: Selected Results for Control Variables: All Education Groups Pooled (asymptotic standard errors in parentheses)

Dependent Variable $=$ Single Head

\begin{tabular}{|c|c|c|c|c|}
\hline Explanatory Variables & Wh & & $\mathrm{Bla}$ & \\
\hline age 16 & $\begin{array}{l}-0.0875^{\text {*** }} \\
(0.0036)\end{array}$ & $\begin{array}{l}-0.0875^{* * *} \\
(0.0036)\end{array}$ & $\begin{array}{l}-0.4090^{* * *} \\
(0.0241)\end{array}$ & $\begin{array}{l}-0.4093^{\text {*** }} \\
(0.0241)\end{array}$ \\
\hline age 17 & $\begin{array}{l}-0.0705^{* * *} \\
(0.0032)\end{array}$ & $\begin{array}{l}-0.0705^{* * *} \\
(0.0031)\end{array}$ & $\begin{array}{l}-0.3299^{* * *} \\
(0.0168)\end{array}$ & $\begin{array}{l}-0.3308^{* * *} \\
(0.0169)\end{array}$ \\
\hline age 18 & $\begin{array}{l}-0.0473^{* * *} \\
(0.0030)\end{array}$ & $\begin{array}{l}-0.0473^{* * *} \\
(0.0030)\end{array}$ & $\begin{array}{l}-0.2209^{* * *} \\
(0.0122)\end{array}$ & $\begin{array}{l}-0.2207^{\text {*** }} \\
(0.0123)\end{array}$ \\
\hline age 19 & $\begin{array}{l}-0.0319^{* * *} \\
(0.0022)\end{array}$ & $\begin{array}{l}-0.0319^{* * *} \\
(0.0022)\end{array}$ & $\begin{array}{l}-0.1632^{* * *} \\
(0.0080)\end{array}$ & $\begin{array}{l}-0.1625^{\text {*** }} \\
(0.0080)\end{array}$ \\
\hline age 20 & $\begin{array}{l}-0.0212^{* * *} \\
(0.0014)\end{array}$ & $\begin{array}{l}-0.0212^{* * *} \\
(0.0014)\end{array}$ & $\begin{array}{l}-0.0976^{* * *} \\
(0.0103)\end{array}$ & $\begin{array}{l}-0.0973^{\text {*** }} \\
(0.0103)\end{array}$ \\
\hline age 21 & $\begin{array}{l}-0.0159^{* * *} \\
(0.0019)\end{array}$ & $\begin{array}{l}-0.0158^{* * *} \\
(0.0019)\end{array}$ & $\begin{array}{l}-0.0599^{* * *} \\
(0.0068)\end{array}$ & $\begin{array}{l}-0.0598^{* * *} \\
(0.0067)\end{array}$ \\
\hline age 22 & $\begin{array}{l}-0.0085^{* * *} \\
(0.0014)\end{array}$ & $\begin{array}{l}-0.0085^{* * *} \\
(0.0015)\end{array}$ & $\begin{array}{l}-0.0351^{* * *} \\
(0.0073)\end{array}$ & $\begin{array}{l}-0.0351^{\text {*** }} \\
(0.0072)\end{array}$ \\
\hline age 23 & $\begin{array}{l}-0.0056^{* * *} \\
(0.0012)\end{array}$ & $\begin{array}{l}-0.0056^{* * *} \\
(0.0012)\end{array}$ & $\begin{array}{l}-0.0339^{* * *} \\
(0.0073)\end{array}$ & $\begin{array}{l}-0.0338^{\text {** }} \\
(0.0073)\end{array}$ \\
\hline ed 0 & $\begin{array}{l}0.0259^{* * *} \\
(0.0044)\end{array}$ & $\begin{array}{l}0.0259^{* * *} \\
(0.0044)\end{array}$ & $\begin{array}{l}0.0806^{* * *} \\
(0.0209)\end{array}$ & $\begin{array}{l}0.0807^{\text {***}} \\
(0.0205)\end{array}$ \\
\hline ed 1 to 4 & $\begin{array}{l}0.0221^{* * *} \\
(0.0041)\end{array}$ & $\begin{array}{l}0.0220^{* * *} \\
(0.0042)\end{array}$ & $\begin{array}{c}0.0563^{*} \\
(0.0313)\end{array}$ & $\begin{array}{c}0.0589^{*} \\
(0.0314)\end{array}$ \\
\hline ed 5 to 8 & $\begin{array}{l}0.0240^{* * *} \\
(0.0053)\end{array}$ & $\begin{array}{l}0.0240^{* * *} \\
(0.0053)\end{array}$ & $\begin{array}{l}0.1043^{* * *} \\
(0.0086)\end{array}$ & $\begin{array}{c}0.1054^{\text {*** }} \\
(0.0086)\end{array}$ \\
\hline ed 9 & $\begin{array}{l}0.0292^{* * *} \\
(0.0023)\end{array}$ & $\begin{array}{l}0.0292^{* * *} \\
(0.0023)\end{array}$ & $\begin{array}{l}0.1074^{* * *} \\
(0.0086)\end{array}$ & $\begin{array}{l}0.1075^{\text {***}} \\
(0.0085)\end{array}$ \\
\hline ed 10 & $\begin{array}{l}0.0238^{* * *} \\
(0.0021)\end{array}$ & $\begin{array}{l}0.0238^{* * *} \\
(0.0020)\end{array}$ & $\begin{array}{l}0.0938^{* * *} \\
(0.0067)\end{array}$ & $\begin{array}{l}0.0945^{\text {***}} \\
(0.0067)\end{array}$ \\
\hline ed 11 & $\begin{array}{c}0.0149^{* * *} \\
(0.0016)\end{array}$ & $\begin{array}{c}0.0148^{* * *} \\
(0.0016)\end{array}$ & $\begin{array}{l}0.0617^{* * *} \\
(0.0101)\end{array}$ & $\begin{array}{c}0.0617^{\text {*** }} \\
(0.0101)\end{array}$ \\
\hline
\end{tabular}




\section{Table 4 (ctd): Selected Results for Control Variables: All Education Groups Pooled}

(asymptotic standard errors in parentheses)

Dependent Variable=Single Head

\begin{tabular}{|c|c|c|c|c|}
\hline Explanatory Variables & \multicolumn{2}{|c|}{ Whites } & \multicolumn{2}{|c|}{ Blacks } \\
\hline ed 13 to 15 & $\begin{array}{l}-0.0129^{* * *} \\
(0.0013)\end{array}$ & $\begin{array}{l}-0.0129^{* * *} \\
(0.0013)\end{array}$ & $\begin{array}{l}-0.0673^{* * *} \\
(0.0083)\end{array}$ & $\begin{array}{l}-0.0681^{* * *} \\
(0.0084)\end{array}$ \\
\hline ed 16 and over & $\begin{array}{l}-0.0263^{* * *} \\
(0.0027)\end{array}$ & $\begin{array}{l}-0.0262^{* * *} \\
(0.0027)\end{array}$ & $\begin{array}{l}-0.1412^{* * *} \\
(0.0326)\end{array}$ & $\begin{array}{l}-0.1410^{\text {*** }} \\
(0.0327)\end{array}$ \\
\hline log adult male wage & $\begin{array}{l}-0.0254^{* * *} \\
(0.0076)\end{array}$ & $\begin{array}{l}-0.0141 \\
(0.0137)\end{array}$ & $\begin{array}{l}-0.1973^{* * *} \\
(0.0614)\end{array}$ & $\begin{array}{r}0.0640 \\
(0.0981)\end{array}$ \\
\hline adult male unemplt rate & $\begin{array}{r}0.0557 \\
(0.0344)\end{array}$ & $\begin{array}{r}0.0125 \\
(0.0454)\end{array}$ & $\begin{array}{r}0.2315 \\
(0.1842)\end{array}$ & $\begin{array}{r}0.0823 \\
(0.3683)\end{array}$ \\
\hline $\begin{array}{l}\text { supply \& demand vars? } \\
\text { Joint tests: }\end{array}$ & no & yes & no & Yes \\
\hline $\begin{array}{l}\text { Adult male wages and } \\
\text { unemployment }\end{array}$ & $p=0.0016$ & $p=0.5818$ & $p=0.0019$ & $p=0.7456$ \\
\hline Supply \& Demand Vars & --- & $\mathrm{p}<.0000$ & --- & $\mathrm{p}<.0000$ \\
\hline
\end{tabular}

Notes: Entries are partial derivatives evaluated at dependent variable means. Other control variables include: year dummy variables, age and education interactions with year dummies, msa dummies, and msa trends. The age and education coefficients are main effects which measure the impact of these variables for 1970, since the equations also include age and education interactions with 1980 and 1990 dummy variables. Reference categories are 12 years for education and 24 years old for age.

*** Significantly different from zero at the 1 percent level on a two-tailed test.

* Significantly different from zero at the 10 percent level on a two-tailed test. 
Table A1: The 67 MSAs Used and Their 1980 and 1990 Populations

MSA/CMSA NAME

Akron, $\mathrm{OH}$

Atlanta, GA

Austin, TX

Baltimore, MD

Baton Rouge, LA

Beaumont--Port Arthur--Orange, TX

Birmingham, AL

Boston, MA

Buffalo, NY

Charlotte, NC

Chicago, IL

Cincinnati, $\mathrm{OH}$

Cleveland, $\mathrm{OH}$

Columbia, SC

Dallas, TX

Dayton, $\mathrm{OH}$

Detroit, MI

Flint, MI

Fort-Lauderdale--Hollywood, FL

Fort Worth, TX

Gary--Hammond--East Chicago, IN

Greensboro--Winston--Salem--High, NC

Hartford, CT

Houston, TX

Indianapolis, IN

Jackson, MS

Jacksonville, FL

Jersey City, NJ

Kansas City, MO--KS

Knoxville, TN

Little Rock--North Little Rock, AR

Los Angeles--Long Beach, CA

Louisville, KY

Memphis, TN

Miami, FL

Milwaukee, WI

Mobile, AL

Nashville--Davidson, TN

New Haven, CT

New Orleans, LA

New York, NY

Newark, NJ

Newport News--Hampton, VI

Norfolk--Portsmouth, VI

Oklahoma City, OK

Paterson--Clifton--Passaic, NJ

Philadelphia, PA
1980 Population

1990 Population

660,328

$1,687,906$

419,573

$2,174,023$

366,191

334,776

806,282

$3,662,832$

$1,242,826$

474,650

$7,103,624$

$1,401,491$

$1,898,825$

410,088

$1,957,378$

830,070

$4,044,284$

520,487

$1,018,200$

928,529

642,781

681,004

807,766

$2,885,555$

$1,166,575$

320,425

571,003

556,972

$1,305,728$

464,810

393,774

$7,477,503$

835,011

826,612

$1,625,781$

$1,397,143$

443,536

619,665

761,337

$1,187,073$

$10,800,000$

$1,762,840$

302,983

748,241

758,558

$1,292,970$

$4,716,818$
657,575

$2,177,495$

576,407

$2,348,218$

378,918

319,906

818,553

$3,783,817$

$1,189,288$

595,644

$7,261,176$

$1,452,645$

$1,831,122$

453,331

$2,553,360$

843,835

$3,912,679$

505,227

$1,255,488$

$1,267,268$

604,526

750,332

851,783

$3,470,254$

$1,249,822$

341,602

672,971

553,099

$1,425,365$

489,968

413,843

$8,863,164$

817,118

876,269

$1,937,094$

$1,432,149$

476,923

681,740

804,219

$1,156,383$

$11,100,000$

$1,693,378$

346,260

910,181

848,273

$1,278,440$

$4,856,881$ 
Table A1: The 67 MSAs Used and Their 1980 and 1990 Populations (ctd)

\begin{tabular}{lrr}
\hline MSA/CMSA NAME & 1980 Population & 1990 Population \\
\hline & & \\
Phoenix, AZ & $1,509,052$ & $2,122,101$ \\
Pittsburgh, PA & $2,263,894$ & $2,097,447$ \\
Portland, OR & $1,242,594$ & $1,412,344$ \\
Richmond, VI & 591,719 & 693,517 \\
Rochester, NY & 882,321 & 907,309 \\
Sacramento, CA & $1,014,002$ & $1,355,104$ \\
San Antonio, TX & $1,035,508$ & $1,250,267$ \\
San Bernardino--Riverside--Ontario, CA & $1,558,182$ & $2,588,793$ \\
San Diego, CA & $1,861,846$ & $2,498,016$ \\
San Francisco--Oakland, CA & $3,250,630$ & $3,686,592$ \\
Seattle--Everett, WA & $1,607,469$ & $1,972,961$ \\
Shreveport, LA & 333,079 & 334,341 \\
St. Louis, MO & $2,303,726$ & $2,367,194$ \\
Tampa--St. Petersburg, FL & $1,375,491$ & $1,685,713$ \\
Toledo, OH & 713,772 & 709,230 \\
Trenton, NJ & 307,863 & 325,824 \\
Tulsa, OK & 568,936 & 605,901 \\
Washington, D.C. & $2,966,209$ & $3,524,913$ \\
West Palm Beach, FL & 576,863 & 863,518 \\
Wilmington, DL & 523,221 & 578,587
\end{tabular}

